\title{
A European Perspective on Consumer Loans and the Role of Credit Registries: the Need to Reconcile Data Protection, Risk Management, Efficiency, Over- indebtedness and a Better Prudential Supervision of the Financial System
}

\section{Federico Ferretti}

\begin{abstract}
The paper examines the role of Credit Registries in the context of European consumer credit markets and the current policies of the EU in this area. It attempts to show the institutional challenges relating to some competing rights or interests among consumers and financial institutions, and the need for a strengthened prudential supervision of the financial system as evidenced by the recent crisis whose effects have spread into the global economy. In particular, it shows that there is a conflict between the right to data protection of consumers, the risk-management interests of lenders, and the prudential supervision of the credit system. The ultimate goal, thus, is to present some weaknesses of the current arrangements and to put forward a proposal that is probably controversial but that is intended to stimulate a debate from an alternative policy perspective that is wider than the current one.
\end{abstract}

Keywords Consumer credit - Credit data · Risk-management - Data protection · Overindebtedness · Prudential supervision· Institutions

\section{Introduction}

Consumer credit reporting has become the instrument most extensively used by lenders to underwrite decisions on borrowings or the supply of goods and/or services to consumer customers. Lenders, in fact, access credit reference databases managed by third party providers (Credit Registries) in order to evaluate a consumer's credit application and his or her creditworthiness. They provide to the credit industry and the market organized information on the performance of consumer borrowers, gathering information on their payment history and accounts, and issuing a credit report prior to the underwriting of a loan or the supply of goods and/or services.

\footnotetext{
Avv. Federico Ferretti $(\bowtie)$

Lecturer in Law, Brunel Law School, Brunel University, Kingston Lane, Uxbridge, UB8 3PH, United Kingdom

e-mail: Federico.Ferretti@brunel.ac.uk or fed.ferretti@libero.it
} 
Credit Registries are present in most EU Member States but their institutional structure varies depending on different policy objectives and the function that they perform in the economy and society. Examples of such objectives are the stability of the financial system, the fight against over-indebtedness of consumers, or a riskmanagement tool in the interest of the profitability of the retail credit industry. Such distinction of the role of credit information providers reveals the distinction between public and private Credit Registries. While the former is institutionally designed to address the stability of the financial system and monitor the indebtedness of consumer households, the latter offers to the market risk-management tools to enhance economic efficiency and the profitability of credit providers irrespective of whether these are banks lending the money of third-parties (depositors) or any other entity doing business through the provision of credit in return for profit (Jappelli and Pagano 2000, Jappelli and Pagano 2003, Jappelli and Pagano 2006, Ferretti 2008).

Thus, the aim of this paper is to explore the role of Credit Registries in the EU, by attempting to show that the current provision of information to the consumer credit market presents some problematic aspects. Arguably, one of the most important ones refers to the function that Credit Registries perform in the economy and society. Currently, in fact, there seem to be ambiguities about such a function or the function that they ought to perform to serve the market.

On the one hand, it should be stated that the role of information as a riskmanagement tool is to enhance the economic efficiency and the profitability of credit providers irrespective of whether these are banks lending the money of third-parties (depositors) or any other entity doing business through the provision of credit in return for profit. This includes any business entity that provides credit to consumers outside the traditional way of crediting via banks, such as, for example, the variety of finance companies present in the Member States, telecommunications, remote-sales businesses, estate agents on behalf of landlords, etc. On the other hand, one should look at the role of information in credit markets for the monitoring of the indebtedness of consumer households and the prudential-supervision of the soundness of the financial system in the public interest.

This seems also particularly important in light of the new Consumer Credit Directive 2008/48/EC which, amongst its provisions, aims at creating an efficient and competitive single consumer credit market in an environment in which consumers 
receive adequate protection. Article 8(1) explicitly requires creditors, when necessary, to consult relevant databases. ${ }^{1}$

Moreover, the above distinction of the role of credit information providers has important implications over the existence and balancing of competing rights and interests that exist among consumers, financial institutions, and the general public.

In fact, when processing and sharing personal financial information of individuals, the right of data protection is at stake. Data protection, however, is a legal right fully embedded in EU law which could be sacrificed or balanced only if opposed by prevailing rights or the general interest. This is also confirmed by the same Consumer Credit Directive 2008/48/EC which in Article 9(4) clearly states that database access "shall be without prejudice to the application of Directive 95/46/EC" on data protection.

Consequently, as important legal rights and liberties are involved, the function of Credit Registries should be to clearly specify the design of the underlying databases and the institutional form that they take. Therefore, this paper states that it makes an important difference whether a Credit Registry performs a public function or a function in the private interest of credit providers.

Finally, the recent financial crisis, whose effects have spread into the global economy, seems to confirm that when Credit Registries have been used as a riskmanagement tool they have played a role in determining the segmentation of consumer credit markets into prime and sub-prime borrowers rather than offering an instrument to supervise the system. Hence, the ultimate goal of this paper is to present some important weaknesses of the current arrangements and to put forward considerations aimed at verifying whether it could be possible to reconcile the respect of the legal right to data protection of consumers, the risk-management and efficiency of credit providers, and a better prudential supervision of the financial system capable of monitoring its soundness and the levels of indebtedness of consumer households.

\section{The Role of Credit Registries in the Consumer Credit Market}

Typically, the process of granting credit begins when a potential customer approaches a lender and applies for credit or services/goods to be paid at a later stage. In the event

\footnotetext{
${ }^{1}$ Directive 2008/48/EC of 23 April 2008, OJ 2008 L 133/66.
} 
the latter agrees to enter the credit agreement, such a relationship ends when the last statement of the credit line is paid back in accordance with the same agreement or, in the worst case scenario, when the credit is unrecoverable and/or disregarded following a debt recovery proceeding and a judicial procedure, or the judicial declaration of insolvency of the borrower. The recourse to debt collection procedures and legal actions, however, does not guarantee to lenders the recovery of the debt and, in any event, they are considered an instrument of last resort as they are perceived to be both costly and time-consuming (Bertola et al. 2006, San José Riestra 2002).

Thus, risk-assessment and applicants screening have become particularly important for the consumer credit industry which has to deal with a large number of small-sum (often unsecured) credit lines. It is widely agreed, in fact, that in this sector profitability is only achieved by minimising the risk while ensuring that a sizeable volume of credit lines is granted. Hence, credit grantors consider information about borrowers vital for their risk-assessment purposes. Moreover, the small size of consumer loans means that it is not cost-efficient to implement the screening of consumers on a case by case basis (Bertola et al. 2006, San José Riestra 2002).

Usually, when lenders evaluate borrowers to determine their creditworthiness for credit-risk assessment and management, they interview the applicants and ask them directly for personal information together with the relevant supporting documents. At the same time, they seek and gather information from their own databases developed through years of experience and business practice in the credit market. Such a source of information, however, is incomplete as it covers a lender's own past and present customers, but it does not contain data about the same customers' past and/or present relationship with other financial institutions nor, what is even worse from the lenders point of view, information about new (potential) customers and their past and/or present relationship with other providers.

Thus, it is with the view to supplement comprehensive information about potential new customers that Credit Registries emerged and developed in the past few decades. At present, said missing sought-after information is made available to lenders through data sharing thanks also to the development of increasingly sophisticated information technologies.

A further secondary use that can be made of such information is that of scoring consumer clients. This is a related, but separate and additional, use of personal information that avails itself of distinct technologies. It is a product that is a derivative 
from credit histories. It adds additional features and allows further uses of credit data integrated with other data sources for additional purposes. Credit scoring, in fact, is a classification and profiling technique. It is essentially a way of recognising different groups in a population according to certain features, expressed by a combination of personal data including credit histories and other non-personal information, and differentiating them on grounds of parameters and classifications set a priori from statistics for a predictive purpose. In technical terms credit scoring models are mathematical algorithms or statistical programmes that determine the probable repayments of debts by consumers, assigning a score to an individual based on the information processed from a number of data sources and categorising credit applicants according to risk classes. They involve data mining techniques which include statistics, artificial intelligence, machine learning, and other fields aiming at getting knowledge from large databases (see, for example, Bigus 1996, Desai et al. 1997, Diana 2005, Handzic et al. 2003, Jensen 1992, Yobas et al. 2000). Credit scoring shares a number of issues with consumer credit reporting, as a large amount of personal data used to generate the score is built upon the latter. However, it also presents peculiar features and raises separate problems - such as, for example, issues of automated decision-making, discrimination, profiling, classification, relevance, proportionality, and accuracy - that deserve separate and additional legal analysis but are beyond the purpose of this study (see, for example, Ferretti 2009).

In economic theory, Credit Registries have evolved as organisations providing information sharing devices in the financial system in order to meet the problem of asymmetrical information between borrowers and lenders. As seen, a credit transaction involves risks or uncertainties about the ability and/or willingness of the debtor to repay (so-called "transactional risks"). At the time of contracting, lenders want to assess whether borrowers will have the ability to pay when the repayment is due and/or that they will want to pay back their debt. These are two different types of risk because some people may be able to pay but are unwilling to do so, or vice versa, they do want to pay but due to unexpected changes in their circumstances may be unable to pay when the money is due. In this context, economists have identified the problem of asymmetrical information as the a problem that a party has when it does not have the same information as the other party regarding the risks involved, i.e., one party knows less than the other (as distinct from a situation where a party has less information than the ideal, known as "imperfect information"). In simple terms, 
lenders want to avoid lending money that will not be repaid: if they do not have the same information as borrowers, they will incur a higher risk of making bad business (Berger and Udell 1995, Diamond 1991, Jappelli and Pagano 2002, Stiglitz and Weiss 1981).

The unwillingness to repay is known as "moral hazard." It refers to the risk which arises from personal, as distinguished from physical, characteristics of a borrower that increase the possibility of an economic loss. It is a phenomenon normally associated with business credit: it occurs when entrepreneurs have incentives to invest in risky projects-when a larger proportion of the cost is funded by a lender. If the project is successful, they have much to gain from any excess return, but if the project fails their losses would be limited by bankruptcy. Hence, in this circumstance, as lenders will suffer much of the actual economic losses, borrowers do not have the incentives to act prudently and may take excessive risks to attempt to maximize returns. Investments, then, could possibly become safer if entrepreneurs have more to lose, in particular if they are forced to bear a portion of the risk (Bertola et al. 2006).

But moral hazard is now considered directly relevant also for the behaviour of consumers in the use of consumptive credit every time that a repayment reflects the willingness, not the ability, to honour one's debts. As the theory explains, when deciding to repay, a rational agent weighs the gain of failing to repay vis-à-vis the punishment for default. Since small-size debts could not be cost-effective to recover by lenders, and debtors may receive no or little punishment by the law (it may take the form of personal bankruptcy in the few jurisdictions where it exists), a number of consumers may become prone to moral-hazard (willingly deciding not to repay their debts) (Bertola et al. 2006).

Thus, by making available rapid access to standardized information on potential borrowers, Credit Registries represent the response to the demands of the market for this type of data, i.e., the needs of banks and other financial intermediaries.

\section{The Institutional Framework of Credit Registries in the EU}

From an institutional point of view, the main differentiating factor on how credit registries operate across Europe could be grouped under two main categories based on ownership: (a) privately owned credit information systems, also known as Credit 
Reference Agencies (CRA); and (b) Public Credit Registries (PCR) generally managed by central banks or other national supervisory authorities (see Miller 2003).

The state of affairs in Europe appears to be a mixed one: while in certain markets only PCR operate ${ }^{2}$, in the majority of them the consumer credit reporting business has been left to free market forces. ${ }^{3}$ In some Member States, however, PCR and CRA coexist. ${ }^{4}$

\section{CRA}

Consumer credit information systems in the EC are in most cases privately owned, normally in the form of companies with no restrictions on the type of shareholders, which may be either banks or other financial firms, as well as any other third-party market players. After all, in such circumstances CRA are profit-seeking incorporated companies that are subject to the same rules and regulations as every incorporated company doing business in the marketplace.

Typically, CRA have a broad range of client members, from banks to non-bank lenders including a wide array of businesses and agencies. Consultation by lenders of CRA databases is not mandatory by law prior to the underwriting of credit and is carried out on a voluntary basis. Crucially, as participation by lenders in a privately owned consumer credit information system is not compulsory, the rules relating to the functioning of the system itself are not imposed by law or regulation but are contracted in a typical supplier-client relationship. The negotiating power of a lender changes from country to country depending on a number of factors, including for example competition in that market and/or maturity of the system (i.e., whether the CRA is a start-up activity with no or little client members or a well established one with wide market participation, as well as other conceivable situations in the between). The consumer's credit data collected and processed by CRA are supplied to the agencies by the lenders themselves, who build the CRA databases to share the information about their customers. CRA often claim that the information is supplied by the lenders on a reciprocal basis, i.e., the lenders are able to access the databases only if they contribute to it for the benefit of all the other contributing member

\footnotetext{
${ }^{2}$ Belgium and France.

${ }^{3}$ Denmark, Estonia, Finland, Greece, Cyprus, Hungary, Ireland, Malta, The Netherlands, Poland, Sweden, and the UK.

${ }^{4}$ Austria, Bulgaria, Czech Republic, Germany, Italy, Latvia, Lithuania, Portugal, Romania, Slovakia, Slovenia, and Spain.
} 
lenders. However, this mechanism of reciprocity relies on agreements between private parties and there is no ad hoc law or regulation in place to enforce it.

CRA also provide their clients with related additional services, in particular statistical models to produce and sell credit scoring services by which they rate borrowers according to their credit history and their (believed) profile derived from the processing of information from different data sources. Where a wide range of data is available, the models may be intensively and increasingly used for purposes other than the assessment of borrowers' creditworthiness, for example scoring customers to promote financial products, price loans, manage credit limits, etc. Very importantly, all these activities are, as a matter of fact, marketing activities that help lenders to segment the market and the client base and price loans, which also founded and helped the idea of having prime and subprime borrowers.

In the end, CRA activities serve the risk-management and marketing needs of the financial industry (broadly defined, i.e., including both the banking and the nonbanking sector) and are designed to favour the increase of profitability.

As happens in every private sector market economy, where companies are driven by the need to make profits and prevail over competitors, CRA are continually persuaded to study, develop and commercialise new products or services to retain their existing clients and/or acquire new ones, thus using data mining techniques on credit reference data and other data sources at their disposal - personal data are, after all, their core business and asset.

\section{PCR}

The picture illustrated above changes in those countries where public authorities have taken an active role in the management of Credit Registries.

The Committee of Governors of the European Central Bank defines PCR as information systems "designed to provide commercial banks, central banks, and other regulatory bodies with information about the indebtedness of firms and individuals vis-à-vis the whole banking system" (Jappelli and Pagano 2003).

PCR are institutions typical of continental Europe, where they first originated and developed with the objective of providing an information system for supervisors to analyse financial institutions' (banks!) portfolios. Reportedly, Germany established the first PCR in 1934, followed by France in 1946, Italy and Spain in 1962, and Belgium in 1967 (Miller 2003b). 
From the definition provided hitherto, it appears clear that the information collected by PCR serves mainly two purposes: (i) to conduct the prudential supervision of banks, monitoring the health and soundness of the overall financial system of a country; and (ii) to assess and monitor the indebtedness of borrowers, both legal and natural persons.

The first purpose means that PCR exercise a public function by furthering the general stability of the banking and payment system. As such, only banks participate in the system and are subject to the underlying rules, unlike CRA that also take in non-bank lenders as client members. This public function is alien to the information sharing systems of CRA that are designed to provide services in the interest of the profitability of a larger variety of lenders that includes, but is not limited to, banks. In this respect, CRA databases are accessible by an indefinite number of potential client members, as they are conceived as open systems with the additional incentive of bringing an increasing number of subscribers into play to respond to competition pressures.

PCR, by contrast, respond to the need for safeguarding the financial stability of the national system, which requires the monitoring of the safety and soundness of banks. This is also referred to as "prudential supervision" to emphasize the "prudence" needed to manage banks, because - in very simple terms - banks collect and hold peoples' savings/deposits, are a vital source of credit for businesses, and manage the payments system.

Of course, prudential regulation, as with any public intervention in the market, has costs. The collapse of a bank, however, is very likely to have negative effects on other banks because of the knock-on effect that the failure to meet its obligation has on the complex chains of transactions of the banking system (a phenomenon known as "systemic risk"). The failure of a bank or parts of the banking system, then, is liable to have devastating effects on the economy at large and people's lives. Failure of one bank may also affect the confidence of other financial intermediaries even if they are not directly implicated. Moreover, depositors may lose their money. The latter also need protection because at the time of banking they do not have the information that would enable them to assess the solvency and viability of a bank for their savings/deposits to be safe. Thus, traditionally the benefits for the safety and soundness of the system are perceived to outweigh the costs for banks of abiding by 
the authorities' prudential regulations (Brealey et al. 2001, Cartwright 2004, Lastra 1996).

The supervision of the financial system encompasses a number of complex issues and elements that are far beyond the scope of this work. What is relevant for this discussion is that, among the elements to achieve it, there is the need for the authorities in charge of such a public function to have adequate and timely information about the behaviour, leverage, and condition of banks vis-à-vis the whole system. Among the many types of information needed by the authorities - such as asset quality, capital adequacy, liquidity, internal systems of control and security, income and dividends, foreign operations, and so on - is included the regular reporting on past due loans and non-performing loans. This not only allows supervisors to be in control and have the information on the condition and performance of the supervisees to intervene in time in case of problems, but it also constitutes an instrument to promote transparency to favour greater reliance on market discipline. As far as this latter component is concerned, banks benefit from supervision in that they are provided with the instruments to control the quality of their loans. To favour this, PCR provide banks and supervisors with information about the indebtedness of borrowers vis-à-vis the whole system (Brealey et al. 2001, Cartwright 2004, Lastra 1996).

The described different function of PCR from CRA offers an account of the form that the former take, as well as the design of the information system. In fact, although PCR operate in many respects like the privately owned CRA, substantial differences exist between the two.

As in the case of private CRA, there is a two-way flow of customers' credit data between the credit grantors and the PCR. However, the key difference between PCR and CRA is that, as anticipated, the former are generally managed by central banks or other states' regulatory authorities. Essentially, financial institutions that are under the supervision of a country's central bank or supervisory authority are required to report certain credit data on a regular basis to the PCR by law or other regulation. Thus, as participation in a PCR is compulsory, its rules are imposed by law or regulation, not under contract as occurs with CRA. This compulsory nature also means that PCR have complete coverage of the financial institutions of a country, and no bank lenders are left out as may happen when parties are free to negotiate whether to take part in a system or not, or which system to be part of if more than one exists (as it happens in 
those countries where more than one CRA exist) (Jappelli and Pagano 2000, Jappelli and Pagano 2006).

Equally, PCR have a legal basis for demanding that reporting lenders remedy possible inaccuracies or make available missing data. Failure to comply can result in sanctions that, by law, PCR may impose (generally, penalty fees followed by supervisory actions) (Miller 2003b).

Indeed, such mandatory reporting and rules of participation represent a fundamental difference between PCR and CRA and have a decisive impact on the legal standing of consumer credit information systems.

In a different way, the assessment and monitoring of the indebtedness of borrowers (the element marked as (ii) in the definition above of PCR) leads to another important difference between PCR and CRA, namely, that PCR have universal coverage of all loans above a threshold amount determined by law or regulation (such threshold varies from country to country), and the information consists of credit data disseminated in a consolidated form. This means that, unlike CRA, lenders have access to the total loan exposure of each borrower, there is no detail on individual loans, and no merger with other personal data or data mining occurs. Another important feature is that PCR operate under strict confidentiality for participating banks. Participants are assured not only that the data that they provide are disseminated in aggregate form, but also that they are passed only to other banks and for the sole purpose of credit granting. No secondary uses, data mining, or data manipulation are attached to the system. Of course, the data provided by the banks can always be accessed in detail by the supervisor in charge of the system in pursuance of one's line of duty for the purpose of banking surveillance (Jappelli and Pagano 2000).

In essence, thus, the two way flow involving PCR can be summarised as follows: the first flow is from the participating institutions to the PCR. The latter, in turn, consolidates the data on the loans granted to the same borrower by each bank in order to obtain the total indebtedness, thus reporting the aggregate indebtedness. PCR, therefore, do not report histories of individual loans but the borrower's aggregate position with respect to the entire banking system (Jappelli and Pagano 2006).

As anticipated, until now legislators did not consider information about credit operations below a certain threshold (i.e., small loans and other credit that constitute what today is referred to as "consumer credit") to be either a threat for the prudential 
supervision of a sound national financial system or a concern in relation to indebtedness, "since small loans have little impact on system solvency or risk" (Miller 2003a, pp. 39). In reality, in the past the number of incidents where retail loan defaults have had serious consequences for a lender and, consequently, the financial system, is trivial. If ever, this may occur if a lender is over-exposed in one area of large sum lending such as mortgages and market circumstances become so peculiar that property prices collapse at the same time as interest rates rise (Heffernan 2005). ${ }^{5}$

In those countries where PCR and CRA coexist, the threshold also demarcates the market segment below which CRA operate without the lenders having the opportunity to turn to PCR, while the same cannot be said as far as it concerns the provision of information above such a threshold. ${ }^{6}$ This segmentation, in fact, also enables CRA to collect and store information about operations above the threshold (in detail, rather than in the consolidated form as PCR). This is possible because the law, which makes their communication compulsory to the competent PCR, says nothing about their collection by others, i.e., it is not forbidden. Distinctively, in this upper market segment, CRA are able to collect and provide their member clients with information with a precise degree of detail (for example, particulars of each line of credit a borrower has with reporting lenders) as opposed to the consolidated form that PCR provide by rule of law or regulation. Again, this advantage is possible, as CRA are not bound by the same rules that fix the functioning of PCR (Jappelli and Pagano 2006)

This situation, however, may no longer be considered valid today after the financial crisis, that started in August 2007 and spread worldwide, was triggered by the accumulation of defaults of subprime borrowers (a combination of mortgages and household debit that led to mass defaults and the collapse of the housing market). This circumstance may suggest that all household debts may indeed be a concern for the prudential supervision of the banking system and that the reporting of operations below the thresholds explained above should be reconsidered.

\footnotetext{
${ }^{5}$ It should be noted, in addition, that even in the unlikely event of such an occurrence, banks minimize exposure and the risk of failure through asset securitisation and/or the use of credit derivatives, complex financial operations where third parties - usually market investors - assume responsibility for the credit risk of the securitised assets. See Heffernan 2005, ch. 2.

${ }^{6}$ This, of course, unless a specific law prevents them from doing so.
} 
All the differences between CRA and PCR have induced some to argue that rather than being simple substitutes, the two seem to be complimentary parts of a country's whole credit reporting system (Jappelli and Pagano 2006, see also Jentzsch 2005).

It seems undisputable from all the features discussed so far that, as the situation stands, PCR and CRA cannot be substitutes to the extent that the formers exercise functions in the public interest that the latter are not entitled to perform. PCR, however, can substitute for CRA to the extent that the lenders' debt provisioning remains tightly controlled and the amount of overdue or defaulted debt is controlled. When a borrower that deals with a bank is already indebted, the PCR sends to the concerned lender the borrower's aggregate position vis-à-vis the entire banking system.

\section{Current Institutional Headaches}

As far as CRA are concerned, the existing economic theory predominantly focuses on the economic side of consumer data sharing and insists on the prospective positive effects or results for lenders.

It seems, however, that there is still neither consensus nor sufficient conclusive evidence to prove either their efficacy in the assessment of the creditworthiness of consumers or the validity of such envisaged solution. Indeed, recent experience shows that CRA did not allow one to see and to detect the coming financial crisis originating from households' indebtedness, particularly in the US (and to some extent in the UK) where CRA are mostly used, developed, and sophisticated. On the contrary, for the amount and type of data that they collect, as well as the detail of the information supplied, it was proved that they were used to foster and encourage the segmentation of credit markets and to create prime and subprime markets where those borrowers at a disadvantage (the subprime market) were offered more costly loans that are more burdensome to repay as they are related to the risk-taking of lenders (rather than the other way round where those at disadvantage would pay less in order to be able to meet their repayment obligations). Besides, some have begun to suggest some forms of caution precisely in the interest of consumers.

Interestingly, so far the issue of asymmetric information and the need for information sharing systems has been analysed from the viewpoint of the advantages for lenders, often neglecting the concerns of consumers. If it is true that some literature 
points out some sort of benefits, in pure economic terms, that a thriving consumer credit market may indirectly and ultimately have on those consumers who repay on time and in full, then up to date research focusing specifically on concerns about possible violations or abuse of consumer rights and civil liberties seems almost nonexistent (see Miller 2003a). Intuitively, for instance, consumer credit reporting systems represent a threat to the privacy of individuals. In fact, there are sophisticated and highly technological mechanisms in place, where data from different sources are easily and quickly aggregated, new data are automatically created, and data are disclosed to a potentially unlimited number of third parties for a growing number of expanding purposes.

Certainly, one may reasonably think that CRA induce an increase in the volume of lending, thus indirectly providing important benefits to those with good credit risks and arousing the interest of debtors too. According to this stance, it would be reasonable to expect that an increase in the profits of lenders would unequivocally result in more favourable credit conditions for those who fall within the classification of "good' consumers." This presumption reflects the view that there is a relative or close equivalence between the pursuit of the lenders self-interest in the maximisation of profits and the promotion of the general interest resulting in lower prices for consumers. This idea dates back to Adam Smith and his notion of the "invisible hand." It relies on the economic assumption that in perfectly competitive markets, marginal private benefits equal marginal social benefits, and marginal private costs equal marginal social costs. Thus, in these terms, self-interest always promotes the interest of the community even though this is not part of the original intention (Smith 1776).

As highlighted by many commentators, the traditional assumptions of perfect competition of Smith's theory are that all market actors act rationally, in their own self-interest, with good and full information, all goods and resources are freely transferable, all markets permit free and easy entry and exit, and prior distribution of wealth and resources does not unfairly impact on competition (see for example Malloy 2004). However, it is well accepted today that such assumptions practically never hold true in the real world, a circumstance Adam Smith was aware of (Smith 1790, see also, for example, Stiglitz 2006, Malloy 2004).

Economic arguments on this subject are numerous, and they touch on contentious areas. What appears relevant for this discussion is that, in the situation studied here, the economic advantages would be for some consumers only (the "good" 
ones), while others would be excluded or would be penalised by paying more (those who do not qualify as "good" consumers for not fitting in predefined criteria and who would arguably have more difficulties in repaying their debts and defaulting).

At any rate, whether CRA really serve the interest of a number of debtors or not, seems hardly the point if one embraces the idea that economic efficiency does not stand in isolation. A different but related perspective, for instance, may be that of looking at other social concerns relating to the position of individuals in society, where they are not merely equated to consumers but valued as citizens. As Howells and Weatherill (2005) rightly point out, "if one wished to adjust the position of individuals in society rather than simply treat them as consumers within the economy, then it would not be deemed appropriate to leave the market to its own devices. (...) Wealth maximisation would be subordinated to wealth distribution and the consumer's needs would attract keener attention at the expense of the consumer's ability to pay" (Howells and Weatherill 2005, pp. 3).

By contrast, the economic theory upon which consumer credit reporting by CRA is based seems to largely ignore a standpoint that emphasizes other social concerns that are rooted in equality and the protection of human dignity. For example, this would be the case where there is a tension with the right to privacy and the promotion of civil liberties.

To begin with, it could be argued that there are no fixed rules in the industry and the literature alike as to what constitutes a good credit risk. Assuming that a good credit risk is someone with immaculate repayment behaviour, then the system seems to penalise those with a weaker credit history notwithstanding their personal circumstances. From this point of view, the profiling, classification, and standardisation of the behaviours of individuals not only appear hazardous for the civil right to privacy involved, but also artificial. The ability of these systems to detect atypical behaviours raises new questions and problems because they also make assumptions about what is normal behaviour, where deviation from the established pattern is seen as undesirable or questionable, with all the following implications. Very often, however, contrary to the very foundations of credit reporting, human behaviours are heterogeneous and unpredictable. At any rate, systems that may be beneficial to some consumers but exclude or penalise others could hardly be considered to be in the interest of society as a whole. 
Most importantly, moreover, as will be shown in the following section of this work, it is difficult to think of data sharing instruments in the interest of consumers, which require the necessary sacrifice of individual privacy and are imposed unilaterally by the industry, with no democratic process having taken place and leaving them no option to decide whether or not to take advantage of their alleged benefits.

It is already worth anticipating that it should be taken into account that in Europe at least, data protection rights now benefit from, and should be interpreted in light of, the provisions of the EC Data Protection Directive 95/46/EC, as well as Art. 8 of the European Convention for the Protection of Human Rights and Fundamental Freedoms, and the Charter of Fundamental Rights of the European Union. ${ }^{7}$

It is useful to stress that all the above concerns are exacerbated by the consideration that there is no conclusive or at least empirical evidence - nor a certain relation of cause and effect - as to the connection between the activities of CRA and the predictability of human behaviour.

In addition, the theory that justifies the rationale for CRA has been criticised for being far from complete. According to Jentzsch (2006), for instance, "this literature is primarily incoherent because there are different approaches to information (...). The economic implications of information are multi-dimensional and no model can integrate them all at once" (Jentzsch 2006, pp. 7).

Others have begun to question the economic efficiency of giving a memory to the market, advancing the proposition that giving second chances to defaulting debtors may be justified not only on equity grounds but also on economic grounds (Jappelli and Pagano 2006). Unfortunately, this exploration has remained in its infancy and, as it stands, does not yet inform policy considerations. If anything, however, it shows that other routes could have been explored.

\section{The Current EU Legal and Policy context}

\footnotetext{
${ }^{7}$ Directive 95/46/EC, OJ L 281, 23/11/95, p. 0031-0050.

European Convention of Human Rights, C 364 (2000), p. 0001-0022.

Article 8 of the ECHR - Protection of personal data - states:

"1. Everyone has the right to the protection of personal data concerning him or her.

2. Such data must be processed fairly for specified purposes and on the basis of the consent of the person concerned or some other legitimate basis laid down by law. Everyone has the right of access to data which has been collected concerning him or her, and the right to have it rectified.

3. Compliance with these rules shall be subject to control by an independent authority."
} 
At EU level the creation of an efficient and competitive single consumer credit market in an environment in which consumers receive adequate protection is a concern at the top of the agenda for the completion of the Internal Market. To reach this goal, the Consumer Credit Directive $87 / 102 / \mathrm{EEC}^{8}$ proved to be ineffective. After years of intense discussions, the European Commission and the European Parliament have recently approved the text of a new directive on the harmonisation of the laws, regulations, and administrative provisions concerning credit for consumers. ${ }^{9}$ Among its provisions, Article 8(1) provides that:

"Member States shall ensure that, before the conclusion of the credit agreement, the creditor shall assess the consumer's creditworthiness on the basis of sufficient information, where appropriate obtained from the consumer and, where necessary, on the basis of a consultation of the relevant database. Member States whose legislation requires creditors to assess the creditworthiness of consumers on the basis of a consultation of the relevant database may retain this requirement" (emphasis added).

Looking at the legislative history of the Consumer Credit Directive, the original controversial intention of the Commission was to introduce a duty to responsible lending for lenders and to protect consumers from over-indebtedness by consulting centralised credit databases. Such a proposal was suppressed by the European Parliament and consequently withdrawn by the Commission amid privacy concerns. As a result, in later proposed versions which eventually led to the current text of the Consumer Credit Directive it was conceded that those obligations would go beyond the purpose of the legislation under discussion and it was agreed to omit the regulation of consumer credit reporting, leaving possible concerns about privacy to the existing Data Protection Directive 95/46/EC (Rott 2009, Ferretti 2007).

In the end, all what is left from previous proposals of the current law is an obligation on lenders to assess an undefined "creditworthiness" of consumers. It has to be anticipated that the Consumer Credit Directive excludes from its application agreements for the provision on a continuing basis of services or the supply of goods

\footnotetext{
${ }^{8}$ OJ 1987 L $42 / 48$.

${ }^{9}$ Directive 2008/48/EC of 23 April 2008, OJ 2008 L 133/66
} 
of the same kind [Article 3(c)]. This, therefore, already excludes the applicability of Article 8 above to insurance services, telecommunications, landlords, etc.

Moreover, further exemptions are listed in Articles 2(2) to 2(5) which exclude certain types of agreements from the scope of the Directive, including its Article 8. Examples are credit agreements secured by mortgage or other comparable security, interest-free credit or credit repaid within three months, hiring agreements, a good number of leasing contracts, credit agreements whose total amount of credit is below 200 Euros and above 75.000 Euros, and overdrafts.

Prima facie, thus, someone may be induced to think that there is an explicit requirement to consult either PCR or CRA for all of the remaining types of credit agreements not excluded by the law.

However, what the wording of the provision of Article 8(1) suggests is that the law now requires, before the conclusion of the credit agreement, that lenders assess the consumer's creditworthiness on the basis of sufficient information. This can be done by obtaining the information directly from the consumer where appropriate, and only where necessary by consulting the relevant database. The requisite "where necessary" makes reference to those Member States whose legislation requires lenders to assess by law centralised databases, i.e., PCR (see above). In fact, as Rott (2009) points out, "the total harmonisation character of the Directive prohibits Member States from introducing such an obligation in all cases (even where this is not 'necessary' in the individual case)" (Rott 2009, pp. 199). Consultation to databases such as CRA that is not already covered by national law, therefore, remains nonmandatory and it relies on the market-developed solutions that do already exist.

As far as database access is concerned, the EU legislator's concern is that in the case of cross-border credit Member States must ensure access to databases for lenders from other Member States on a non-discriminatory basis. Again, this does not mean that the consultation in all types of databases (including CRA) is mandatory but that, to prevent distortions of competition among EU lenders, the conditions for access of lenders from other Member States shall be non-discriminatory (Article 9).

Moreover, as anticipated above, the Commission's initial plan to impose centralised databases at national level was dismissed by the European Parliament (see also Rott 2009, pp. 198-199). Crucially, at any rate, Article 9(4) of the Consumer Credit Directive affirms that database access shall be without prejudice to the application of Directive 95/46/EC on the protection of personal data. 
Following the European Commission communication on "A Single Market for $21^{\text {st }}$ century Europe" (European Commission 2007a) accompanied by a Staff Working Document "Initiatives In The Area Of Retail Financial Services" (European Commission 2007b) in September 2008, the European Commission appointed an Expert Group on Credit Histories (EGCH) (European Commission 2008). Such an appointment was made with the objective to identify solutions that will maximize the circulation of credit data within the EU. It was based on the assumption that it is very important to access credit histories of consumers in promoting competitive retail financial services markets (European Commission 2008). Curiously, the EGCH seemed to provide an unbalanced composition of its members in favour of the credit industry and no independent or academic representatives were involved (European Commission 2008).

In May 2009 the EGCH produced a Report which contains a number of recommendations aimed at presenting proposals and informing European policy makers about identifying all legal, regulatory, administrative and other obstacles to accessing, and exchanging credit data at EU level (EGCH 2009). The Report did not depart from the above assumptions of the Commission and did not address a number of important issues such as, for example, conflicts with data protection legislation, privacy and confidentiality, the role that the organisations/institutions involved play in the financial system and/or in society.

Significantly, consumer representatives did not agree with anything that appeared in the Report and refused to endorse it precisely for concerns regarding data protection, as well as the usability and relevance of credit data (European Commission 2009a, see also European Commission 2008).

At the time of writing, the unresolved issue of credit data and histories is under the process of consultation with the relevant stakeholders. Following this, it seems likely that in future there will be EU secondary legislation on credit data and databases. As this is in its embryonic phase in the context of the legal and policy framework described above, the continuation of this paper sets to stress the importance of the existing data protection legislation and put forward an alternative 
and wider perspective to be taken into account by stakeholders and policy makers alike. $^{10}$

\section{Data Protection}

In collecting, processing, and disseminating the personal data of consumers in credit operations, Credit Registries must, like any other European data controller, comply with data protection legislation. As stressed above, even Article 9 of the Consumer Credit Directive requires it explicitly. Moreover, Article 16 of the Lisbon Treaty, as just ratified by all Member States, upgrades the provision on data protection to a "provision of general application" in its Title II alongside other fundamental principles of the EU. It also requires the EU legislator to establish a certain and unequivocal legal framework for data protection. ${ }^{11}$

Directive 95/46/EC on data protection serves the double purpose of both ensuring the free movement of personal data in the EC internal market and guaranteeing a high level of protection for data subjects. It sets out a high level of normative protection. As it establishes a minimum level of harmonisation, the Member States must meet the minimum requirements that it sets and cannot go beyond nor fall short of these minimum standards.

The scope of the Directive, which applies to any operations performed upon personal data (data processing) is to provide for good data management practices on the part of those entities that determine the purposes and means of the processing of personal data (data controllers). It contemplates a sequence of general rules on the lawfulness of the processing of personal data, the principal ones including the following obligations:

\footnotetext{
${ }^{10}$ The consultation process and future updates are available via http://ec.europa.eu/internal_market/finservices-retail/credit/history_en.htm

${ }^{11}$ Article 16 of the Lisbon Treaty reads that "1. Everyone has the right to the protection of personal data concerning him or her. 2. The European Parliament and the Council, acting in accordance with the ordinary legislative procedure, shall lay down the rules relating to the protection of individuals with regard to the processing of personal data by Union institutions, bodies, offices and agencies, and by the Member States when carrying out activities which fall within the scope of Union law, and the rules relating to the free movement of such data. Compliance with these rules shall be subject to the control of independent authorities (...)." The rules adopted under on the basis of Article 16 of the Lisbon Treaty shall be without prejudice of its Article 39 on the common foreign and security policy.
} 
- to inform in an intelligible form data subjects about the identity of the data controller(s) and the use, purpose and recipients of personal data (Articles 10 and 11) so that data subjects do not lose control over them;

- to process personal data only upon obtaining the unambiguous freely given specific consent of data subjects after having informed him/her of the processing of the data (Article $2 \mathrm{~h}$ and $7 \mathrm{a}$ ) or without consent if the processing is necessary for the performance of a contract (Article 7b), compliance with a legal obligation of the data controller (Article 7c), to protect a vital interest of the data subject (Article 7d), or for the performance of a task carried out in the public interest or in the exercise of a public authority (Article 7e);

- to process personal data only for specified, explicit and legitimate purposes (Article 6b) in order to limit data controllers in further uses of personal data and for the purpose for which they were collected;

- to use personal data that are adequate, relevant and not excessive in relation to the purpose for which they are collected and/or further processed (Article 6c);

- to process accurate and up-to-date personal data, taking any reasonable step to ensure the rectification or erasure of inaccurate data (Article 6d);

- to keep the personal data in a form that permits identification of data subjects for no longer than necessary (Article 6e) in relation with the purpose for which they were processed and depending on the nature and type of data in consideration;

- to guarantee the security of the data against accidental, unauthorised access, or manipulation;

- to provide notification to the national supervisory authority before carrying out all or certain types of data processing operations (Article 17).

Ascertaining whether CRA activities truly comply with the law is problematic. There are critical concerns about the necessity, adequacy, and relevance of the type of data involved and the foundations, or assumptions, upon which consumer credit reporting is based in order to determine the predictability of individual human behaviours and/or the real financial capability of borrowers. 
In particular, many doubts arise as far as the legal compliance of information to be given to data subjects is concerned (Art. 10 and 11 of the Directive). The general objectives of transparency and informational self-determination set by the Directive seem seriously compromised by the amount and intelligibility of information that should be provided to individuals, the type and number of personal data processed by CRA, the indefinite number of actors involved in a spill-over data dissemination, and the secondary uses of the same data.

As far as all the other requirements set by the Directive are concerned (i.e., the processing purposes, the adequacy and relevance of the data, accuracy, the data retention period), in the end the whole system seems to rely predominantly on the consent of the data subjects. This is so because in the absence of the universal acceptance of the assumptions upon which consumer credit referencing is based (i.e., past behaviour as predictive of future behaviour and the type of data to determine it), CRA need to rely on the informed consent of data subjects unambiguously agreeing to all the "rules of the game" set by the credit industry unilaterally. Consent, as conceived by the law, is a key element that permits the processing of personal data by data controllers that would otherwise be forbidden. When consent is validly provided by a data subject, this releases data controllers from the restrictions provided by the law in a fashion that has been described as an "opt-in" system, i.e., the processing becomes lawful from the moment such consent is unambiguously expressed.

This issue is even more important in a system that is voluntary, as there is no necessary requirement, neither legal nor natural, to justify the communication and sharing of personal data for the performance of a contract that, after all, is the core of the business of lending. Lending money in exchange for profit (the interests on money lending) is perfectly possible and most probably lucrative even without the intervention of CRA. At the most, data sharing is useful, in the same manner as using personal data for marketing purposes is useful. When consumers interact with business entities, however, the latter do not necessarily have to disseminate the data for marketing reasons, no matter how useful this may be (it is unquestionable that in business terms marketing is a very important activity). Indeed, the processing of data for marketing purposes should be kept separate from the processing of data for the purposes for which they were originally collected. This voluntary aspect about marketing is very well accepted by the business community and legal current practice. Consumer credit data sharing by CRA should not be treated any differently. 
Certainly, lenders have a legitimate interest in wanting to know whether credit applicants are, in their own terms, creditworthy and how much to price loans. After all, they have a legitimate interest in profitability. At the same time, though, consumers have not only a legitimate interest but indeed a right with respect to their informational privacy, and the law recognises and protects that.

This view is reinforced by practice, where CRA and lenders rely on consent for a lawful processing of consumers' data.

But, according to the law, such consent must be informed, unequivocal, specific, and given freely.

Crucially, more than one instance of consent should be required because it would otherwise create a problem of absence of specificity. In fact, it would be a violation of the information privacy principles to ask consumers to sign authorisations, unlimited in subject matter, essentially purporting to give permission to data controllers to process any personal data that they unilaterally decide to be relevant and disclose that information for expanding purposes to any person. By contrast, one of the primary concerns of the Directive is to ensure that data subjects consent specifically to all uses for which the data is processed (Article 7). A processing based on consent cannot be regarded as lawful if sought for general or vague aims, or if the data subject has no possibility of knowing the recipients of his/her data.

Importantly, the above instances of consent should be separate from the consent which a customer gives for the processing of his/her data for the specific purposes of the credit relationship with the lender at stake.

Another fundamental feature is that, as a general rule, each instance of consent should be the free choice of the individual. Arguably, in fact, in data protection terms, consent would be meaningless if people have no option but to consent in order to obtain a benefit or a service that could be provided nonetheless.

It seems to be the case that in the credit reporting process carried out by CRAs, consumers do not have much choice if they do not want to be refused credit. The consumer's consent with regard to the searches to be carried out in the CRAs' databases, for example, seems to be viewed as either mandatory or assumed. Lenders say that the lack of such consent would impede them from taking the credit application any further. 
Moreover, lenders make it a condition in the same instance of consent or in the credit contract that at a later stage they have the right to pass the information concerning such specific credit line to CRA, which in turn will have the right to disseminate the same to their client members, such a condition seemingly nonnegotiable.

In the absence of alternative contracts with different lenders offering similar credit terms (i.e., mainstream lenders) that do not contain the objectionable clause. it may be reasonably suggested that consumers have no option but to accept being included in credit reference databases (Howells 1995).

It is vital to stress once more that the expression of will, in order to be regarded as having been given voluntarily, must refer explicitly to the processing of personal data, and not as a consent to conclude the credit contract. This would already be sufficient reason to maintain that the refusal by a data subject to permit an amount of processing of personal data unnecessary for the provision of a service required should not mean that he/she is failing to consent to that service. A typical example is that of commercial marketing: no one denies that it is an important economic activity that would increase the profitability of an industry and possibly an economic advantage for consumers. It is well accepted in data protection, however, that data controllers may-not obtain consent to process the data for such a purpose on the understanding that the goods or services may not be otherwise be purchased or obtained. According to the Directive, and read in conjunction with the proportionality principle, such a practice of obtaining consent would lack its freely given element (see for example Kuner 2007 ch. 5J., Bainbridge 2005, Jay and Hamilton 2007 ch. 12 and 22). Finally, it has to be taken into account that the so-called "mainstream lenders" are part of a network system, thus leaving no live option to consumers if they do not want to be refused credit. Or - in those few European jurisdictions where money lending is not considered usury for rates above a certain threshold set by the law (as opposed to those Member States that punish such a practice in criminal law, leaving little or no space for lawful subprime lenders) - consumers are left with the alternative option of recourse or resorting to subprime lenders, overpaying for the service. ${ }^{12}$

\footnotetext{
${ }^{12}$ In most Member States interest rates cannot exceed a maximum rate established by law (a so-called "objective control system" approach in the fight against usury). For example, this is the case in Italy, France, Belgium, and the Netherlands. In other Member States the usury rates are determined by subjective case by case decisions of the national competent Courts that in this way exercise a control
} 
With reference to a contract condition which required a consumer to allow his/her personal data to be disclosed mandatorily to CRA, the problem is well synthesised by Howells in his analysis of the determination of the fairness of clauses requiring consent for disclosing positive data vis-à-vis the Unfair Contract Terms Directive 93/13/EEC: ${ }^{13}$ "such a term may be considered unfair if consumers have no option but to accept the term if they desire a particular form of credit and yet be acceptable if other creditors offer them similar credit whilst not requiring such consent" (Howells 1995, pp. 353).

In the end, therefore, as has been noted for other areas of law, consent might be formally free in the sense that there is not a single or traditional method of forcing individuals into a transaction by commercial organisations, but if the costs of not consenting are considerable in relation to the situation at stake, and there are no live options, then consent cannot be said to be materially free (Leader 2006, Becker 1977, Agre 1997).

There is another important aspect of consent. As construed by the data protection legislation, consent is normally a unilateral act, and therefore inherent in its nature is that it can be withdrawn by the data subject at any time (see also for example Carey 2004, Bainbridge and Pearce 2000). Thus, consent may be withdrawn if the data processing is not necessary for the service provided or further processing that is compatible, but still different, from the original purpose may be denied. Once the assessment of the creditworthiness has tested positive and credit has been granted to a consumer, there would be no reason for communicating his/her data to CRA, hence there would be no reason to impede the concerned individual's right to revoke his/her consent to the subsequent processing.

However, consent may not be immediately withdrawn by a data subject especially if it has been given under contractual arrangements which limit its withdrawal. Once more, in legal terms, such an obligation seems to be incorporated in the standard terms of consumer credit agreements, leaving no option to data subjects to exercise the right of withdrawal.

All the above difficulties would probably be acceptable if consumer credit reporting by CRA were a necessary step of the credit granting process or a processing

over usury practices a posteriori (the so-called subjective control system). For example, the UK and Germany rely on a subjective control system.

${ }^{13}$ OJ 1993 L 195/29. 
in the public interest. It is useful to recall that for the processing of data to be considered lawful under these latter circumstances it must be certain that the interest at stake is indeed a legitimate one recognised and protected by law. But the assessment of the creditworthiness of consumers via CRA is actually not lawful and at any rate, consent from the data subject would not even be a necessary requirement by law.

Instead, as in the case of data processing for marketing purposes, an attentive application of the law should lead to a different scenario where consumers are given the choice to be included or excluded from CRA databases. At the same time, however, the freedom for people to decide upon their participation in the system leads to a conflicting reflection: a CRA database comprising only of-individuals who voluntarily accept the inclusion of their data, and who could furthermore withdraw their consent for the processing at any time, would have no reason to exist as it could not even address the rationale and objective of the system itself. In all likelihood, those who eventually decide to be excluded from CRA databases or elect to withdraw their consent every time a negative piece of information is created would largely, though not exclusively, be precisely those customers that a credit reporting system is designed to identify. Indeed, a database designed to be incomplete would be helpless to address any need of the credit industry in the first place.

Paradoxically, therefore, as the system stands it seems that:

(i) the essential option that must be offered to consumers by law to accept or decline inclusion in the system on the one hand, and

(ii) the rationale and scope of consumer credit reporting on the other hand, are incompatible elements that create a vicious circle. Either the industry violates the law abusing consumers' freedom to provide consent, or it abides to this law but feeds a system that is ineffective and has no reason to exist.

In brief, the problem with credit referencing, and then scoring, is that consumers are not presented with a real choice, and if the choice were given, this would be incompatible with the logic of the reporting system itself. But the law must be respected. It has to be noted that the fictitious aspect of consent described has been recently recognised by the German legislator who has decided to omit it in CRA operations in a law that is due to come into force in May $2010 .^{14}$ For all the

\footnotetext{
${ }^{14}$ Act of 29 July 2009 - BGB1 I, p. 2254.
} 
considerations made above and the new status granted to data protection by the Treaty of Lisbon, it remains to be seen whether such a law, that seems to lower the level of normative protection in consumer credit operations, truly complies with EU law. Prima facie this may appear questionable and most probably it would deserve the attention of a separate analysis. Probably what would also be interesting to see is how this law will fit in with any likely future EU legislation on credit histories, as the consultation process underway seems to suggest (see above).

\section{An Institutional and Policy Proposal for Debate}

The following considerations set out to explore whether it would be possible to reconcile the essential needs of the industry with the respect for data protection law, its rationale, and the prudential supervision of the financial system in the general interest. They also intend to give full consideration to the above-discussed current law and policy of the EU as regards the assessment of the creditworthiness of consumers and responsible lending and borrowing, although further studies would be necessary to identify and understand the full meaning of these terms across the EU.

So far, this study has attempted to stress that to the extent that the credit industry in general, and CRA in particular, need to rely on informed freely given consent to legitimise personal data sharing - and, ultimately, to validate the existence of the business - the present system and procedures seem undesirable as they create a tension with the positive law and its rationale. The inclusion of personal data in CRA databases should be left to the voluntary provision by individuals, which most probably would make the system useless for satisfying the needs asserted by the credit industry.

Alternatively, if someone wants to take a different point of view, then the present legal framework is not adequate for the current practice, but this would mean according a higher justificatory status to the activities currently carried out by CRA for the stated purposes. Ultimately, it would entail that the existing law should be amended to allow CRA to mandate the provision of personal data in their databases. For this to be the case and to justify the sacrifice of informational privacy, it would first of all be helpful to have some conclusive or at least robust empirical evidence for the industry's needs as addressed by the present commercial form. Then, very strong arguments should be put forward in order to outweigh the protection of an established 
human right, especially if one considers that the tendency of the EC law-makers and the national Data Protection Authorities is that of further strengthening protection of the civil liberties of citizens living in the EC (European Commission 2003a, European Commission 2003b). It appears, in the end, that the heart of the debate and the fundamental question referring to credit reporting for consumers is how far the latter should be forced to surrender their established rights to informational privacy in the interest of the credit industry (under these circumstances, not the general interest), bearing in mind that the "utilitarian" concerns of lenders cannot necessarily prevail over civil liberty and fundamental human rights concerns. ${ }^{15}$

A compromise solution, which may provide the industry with important information about credit applicants whilst respecting the law and its rationale, could be one that focuses on the distinction between public and private credit registries (CRA vs. PCR). It is inspired by Jappelli and Pagano's submission that private and public arrangements can be substitutes, provided that the crucial parameter in the design of PCR is to set a zero threshold on the reported loans (Jappelli and Pagano 2006). Also, it relies on Recital 32 of Directive 95/46/EC which provides for the law to determine whether a data controller performing a task in the public interest should be a public administration or a legal person governed by public law. ${ }^{16}$ This solution could also partially address policies against raising levels of consumers' overindebtedness.

Actually, should evidence be provided that the reporting of consumer financial information could be carried out in the general interest, then considerations different from those put forward for CRA would apply. ${ }^{17}$ For this to be done, however, it would mean accounting the monitoring of consumer operations as important for the stability and supervision of the financial system, or for control of the indebtedness of individuals vis-à-vis the whole system. ${ }^{18}$ As the Article 29 Working Party warns, it is the "legitimate interest in the preservation and stability of the financial system which justifies the communication of this information to third parties." ${ }^{19}$ This measure,

\footnotetext{
${ }^{15}$ The same concern has been expressed by Howells 1995, pp. 358.

${ }^{16}$ Directive 95/46/EC, Recital 32. The provision also makes reference to a natural or legal person governed by private law "such as a professional association."

${ }^{17}$ However note that it has been stressed elsewhere in this work that, at present, some commentators do not consider consumer credit as a threat for the stability of financial institutions, unless there are other factors that interfere with the economic conditions of a country or the international financial system. ${ }^{18}$ As stressed earlier, these are indeed the two functions of PCR.

${ }^{19}$ Article 29 Working Party on Data Protection, Working Document on Blacklists, 11118/02/EN/final, Adopted on 3 October 2002, 4.
} 
which nevertheless has adverse effects for the privacy of data subjects, should be "taken without losing sight of the principles of the Directive, and specific safeguards must be in place to uphold data subjects' legitimate rights." ${ }^{20}$ So, for example, data subjects should be given the right to be informed about the data processing, the right of access, and the right to have erroneous data relating to them rectified. In that event, however, the requirement of consent would no longer represent the applicable normative provision, thus solving the problem of providing authorisations for data processing and lifting any bureaucratic burden on data controllers.

As explained earlier, such a job is normally carried out by Central Banks or other financial authorities within the framework of secondary industry-specific legislation. The public sector in all Member States is, in fact, governed by the legality principle, the basic rule being the possibility of freely processing data if necessary for the performance of a task carried out in the public interest. Moreover, this view would be in agreement with the stance taken by the Article 29 Working Party when recommending that the sharing of files containing records of a person's payments should have its basis in legislation providing for this course. ${ }^{21}$

In the regulatory context just envisaged, robust rules would need to be present. They would aim at providing the credit industry with essential information whilst preserving the respect for and rationale of data protection legislation.

(i) To begin with, the design of the system would need to reflect the purpose and policy goals of PCR. As their aim is to monitor the soundness of the financial system and the overall indebtedness of borrowers, the underlying uses and type of personal information to be shared would be only those strictly necessary to achieve such clearly defined goals. As specified earlier, PCR would be characterised by strict and unambiguous rules of participation. Among them, for example, there would be no need to detail individual loans, but only to report the total loan exposure of a borrower in aggregate form. Likewise, there would be no indication in the databases of past delays or defaults that have been repaid because no assumption is made that past behaviour is predictive of future behaviour. In fact, there would only be a need to know the existing indebtedness of a borrower. The sharing of data would

\footnotetext{
${ }^{20}$ Ibid.

${ }^{21}$ Ibid.
} 
focus only on outstanding liabilities and repayment levels. Thus again, the distinction between positive and negative information in the database would lose its relevance because it is the amount of remaining debt that shows a borrower's aggregate position vis-à-vis the entire banking system that matters. All the more, then, this principle would apply with reference to those past credit operations that were concluded with timely payments. Finally, because of the rule of strict confidentiality of users, there would be no scope for data mining or data manipulation with other data that may attribute a meaning different from that of the data taken in a separate context ("function creep"). Needless to say, lenders would be able to keep on demanding information from borrowers on a case by case basis, as well as to ask for supporting documents to validate it. Also, they would be still able to use all other public information.

Each lender's own risk-management techniques and skills could even form the basis for a competitive advantage over other lenders, also reflecting this circumstance in the price of credit to be offered. True, the provision of credit would take longer and imply a more attentive screening of unknown potential customers. At the same time, however, this could contribute to tackling an "instant credit culture," thus also addressing policies to educate consumers and contribute to fighting the increasing levels of over-indebtedness of individuals. This type of compromise solution, in the end, may form part of the education to be provided to consumers in the use - or over-use - of credit, indeed a priority in the agenda of European policy-makers. In so doing, it would also respond to increasing demands that over-indebtedness should be a public concern and responsibility. ${ }^{22}$

Likewise, said arrangement would be compatible with the latest policy context set by the EU Commission in the area of the supervision of the stability of the financial system. Following the recent financial crisis, which has highlighted weaknesses in the EU's fragmented supervisory framework along national lines, the Commission has advanced a new Proposal for a Regulation on Community macro prudential oversight of the European financial system. This Proposal aims to establish strong arrangements that properly address the

\footnotetext{
${ }^{22}$ See the principles developed by the European Coalition for Responsible Credit, in Reifner 2008.
} 
interaction and interdependence between micro and macro prudential risks and analysis. In its attempt to redesign and create new institutional structures (such as a European Systemic Risk Board), it urges supervisors to monitor and assess potential risks for financial stability that may arise from developments that can impact on a sectoral level, or at the level of the financial system as a whole. In the performance of their duties, they should have access to all the information necessary and exchange information while preserving the confidentiality of data (European Commission 2009b). To this purpose, PCR could play a role in the supervision of the consumer sector.

(ii) Secondly, there would be a problem with non-bank lenders that do not take part in the banking system, or whose failure does not affect a country's financial stability. These are private organisations that should abide by the same market rules and laws that every person, whether natural or legal, should respect, without benefiting from privileged instruments that may suppress the rights of individuals. If these lending organisations do bad business as a result of their choices, then they should fail. By contrast, if they are good then they should succeed. What matters for this discussion is that there should be no interest in their financial health for the stability of the system as a whole and they should be allowed to fail as any other company does in a market economy.

(iii) Thirdly, consumer credit lenders that are part of the banking system would need to report credit operations to PCR for the assessment of their own financial stability. Such a reporting would be done to an institution that has the legitimacy and the authority to receive it. And, yet again, this is where the role and type of organisation such as CRA institutionally fail. As emphasized earlier, it would rather be the task of PCR to include consumer credit operations in the wider context of financial reporting for the prudential supervision of the system, together with the obligation to abide by the set of rules that follows with the participation in such systems. This, inter alia, would at least carry the advantage for consumers of not only clear and transparent rules and the use of only essential information, but also of accountability measures in place for the respect of rules legitimately set according to a proper legislative or regulatory procedure. 
Arguably, the feature that the set of rules of the system originates from the legality of a legitimate law-making process would represent per se an important guarantee for individual liberty and democracy. Accordingly, in fact, any new rules that place a restriction on human rights such as data protection should undergo a democracy test. This interpretation is supported by the combined reading of Article 6(2) of the EC Treaty and Article 52(3) of the Charter of Fundamental Rights that make explicit reference to the respect for the European Convention for the Protection of Human Rights and Fundamental Freedoms. In its Article 8.2 the Convention provides that there shall be no interference by a public authority with the exercise of human rights "except such as in accordance with the law and is necessary in a democratic society." 23 Without such a legality process, it would mean using consumer credit reporting to make policies without a democratic debate.

(iv) Fourthly, consumers could find a further guarantee in the legitimacy and authority of supervisors/regulators, and a better governance of power which would carry with it measures of accountability. Accountability, in fact, may play a major role in the management of economic and social resources, including the rights of individuals (World Bank 1992). It is a pervasive concept defined as "an obligation owed by one person (the accountable) to another (the accountee) according to which the former must give account of, explain and justify his actions or decisions against criteria of some kind, and take responsibility for any fault or damage" (emphasis added) (Lastra and Shams 2001).

A key element at the core of accountability is the content of the obligation of the accountable, i.e., the obligation of the holder of power to give an account of his decisions or actions, to explain and justify them, and to own the responsibility and take appropriate measures of amendment or redress when error is proved or harm inflicted. The establishment of clear criteria of conduct and specific outcomes are paramount ingredients of the content of such an obligation, for any form of accountability presupposes the existence of objectives or standards according to which an action or decision may be addressed (Lastra and Shams 2001). All these mechanisms of good

\footnotetext{
${ }^{23}$ Council of Europe, Convention for the Protection of Human Rights and Fundamental Freedoms, (ETS No: 005) open for signature November 4, 1950, entry into force September 3, 1950
} 
governance legitimately exist for PCR but are absent as far as CRA is concerned. Still, this issue could prove vital for the pursuit of the general interest in a more transparent environment, thus ultimately in the protection of consumers against possible violations of their rights.

(v) Finally, the European dimension of consumer credit and market integration would require that individuals do not suffer discrimination based on nationality. Likewise, the European lenders should be placed in the position to compete and offer their services European-wide. Thus, the conferment of an information sharing device, in the form envisaged above, to PCRs could make a European exchange of information possible. From the practical side, the relevant authorities presently in charge of supervising the financial system have already developed a communication network amongst themselves, showing that appropriate cooperation is already in place without the hurdle of creating a system from nothing. ${ }^{24}$ PCR in Europe have already started to work together in the so-called Working Group on Credit Registers (WGCR). The Group - that is part of the Banking Supervision Committee of the European System of Central Banks - has finalised a plan for a pan-European data exchange among the PCR of Belgium, Germany, France, Italy, Austria, Portugal, and Spain as well as representatives of the European Central Bank. The plan consists of creating a reporting system that allows data exchange on a regular basis. This undoubtedly represents an embryonic form of crossborder exchange of information on loans even if for the time being it provides information to financial institutions about the indebtedness of only their

\footnotetext{
${ }^{24}$ The European institutional architecture for the regulation and supervision of the financial stability of the system is a rather complex one which was approved in December 2002 by the Council of Economic and Financial Affairs (ECOFIN). The main aim of this fully-fledged reform is to respond to the challenges brought by the ongoing process of financial integration in the EC and the introduction of the Euro currency. It entails a strict cooperation between regulatory and supervisory national authorities, both across sectors and across countries, in order to obtain an optimal knowledge of European crossborder financial activity allowing convergence towards supervisory best practices and ensuring financial stability. The institutional arrangements foresee a sectoral and decentralised model of financial regulation and supervision leaving those functions at national level but ensuring cooperation among the national regulators and supervisors. In compliance with Art. 105(5) of the EC Treaty, the European System of Central Banks contributes to the conduct of the policies pursued by the competent authorities in relation to the prudential supervision of credit institutions. At the same time, the Treaty leaves open the possibility that the European Central Bank, as the institution setting monetary policy, gains some supervisory responsibility with the exception of insurance companies. Thus, the explicit coordination among competent national supervisors and the implicit coordination between the latter and monetary policy-makers take place in the Banking Supervision Committee of the European Central Bank which has become the legitimate forum for cooperation between supervisors and central bankers in the EC. For a detailed description see Nieto and Penalosa 2004.
} 
corporate customers and does not apply to the consumer credit sector (Deutsche Bundesbank 2005).

The major problems behind the creation of interfaces among the consumer credit information systems of the existing PCR seem to be the different designs regarding coverage, reporting thresholds, and type of information reported (Jappelli and Pagano 2006). Nevertheless, the existing technologies in use in the sector support the view that, for such a system to be complemented, radical organisational or innovative measures would not be required. Certainly, there may be one-off costs in the adaptation of existing systems or the creation of new ones for countries that may have a different system in place. However, the benefits identified herein would probably justify them, bearing in mind that the present arrangements for consumer credit reporting by CRA are not cost-free, and include also the profits of the service provider.

(vi) Under recent financial practice, investors in financial markets have been offered and have invested in asset backed securities collateralised with a portfolio of mortgage or other household loans. However, with the system currently in place, in particular CRA, they lacked the information about the quality of the underlying assets and the level of indebtedness of debtors in order to determine the level of risk of their investments. Likewise, also those arranging securitisation transactions, including rating agencies, lacked information about loan portfolios and debtors' indebtedness. This has contributed to the spread of what became toxic assets within financial markets. Probably, with the use of publicly available information via PCR, at least credit rating agencies would have been able to provide more accurate information to investors and to anticipate some problems thus limiting the spread of toxic assets and contributing to more prudent market behaviour.

\section{Conclusions}

In summary, to conclude, the inclusion of consumer financial data, in an appropriately regulated form, in public credit registries may be used not only to strengthen bank supervision but could also serve to improve the quality of credit analysis by financial institutions to the extent that this is necessary for the general interest of financial 
stability and the monitoring of the indebtedness of the individuals towards the system. It would respond to, and comply with, the current requirement of the new Consumer Credit Directive which poses an obligation on lenders to assess the creditworthiness of consumers while at the same time necessitating the respect of the Data Protection Directive 95/46/EC.

On a micro-economic level, lenders would be able to detect and tightly control their credit provisioning and the amount of overdue and defaulted debt in circulation, whilst PCR would supervise and control the level of indebtedness on a macroeconomic basis. ${ }^{25}$ In this way, fundamental privacy rights and civil liberties could be better preserved and, should any sacrifice of the latter occur as an eventual necessity, then it would be in the general interest but still within a regulated environment designed to stem excesses and abuses, including possible secondary uses or any function creep.

Last but not least, the supervisors or regulators of the Member States could legitimately engage in a European exchange of information that could not only strengthen the supervision of the European financial system, but could also foster the Internal Market by removing barriers to the basic Community freedoms and taking a step in support of the creation of a single European market in consumer credit where consumers not only receive adequate protection but, as citizens, are better safeguarded from surveillance, classification, profiling, or social selection and sorting. For this to occur, there would need to be agreement about the standardisation of the type and use of information and the setting of a very low - possibly zero - threshold in PCR (Jappelli and Pagano 2006).

\footnotetext{
${ }^{25}$ For similar considerations about the value of public credit registries see also Majinoni et al 2004. It may be worth a note that the new recommendations of the Basel Committee for Banking Supervision (so-called Basel II) on the methods aimed to determine the necessary capital requirements of banks permit for the first time the latter to group their loans to private individuals into a retail portfolio to be audited by the competent supervisory authorities. CRAs clearly do not and cannot have a role, first of all because of the aims and design of credit reporting systems (information sharing is alien to the analysis of an existing portfolio) and, in any event, lack the necessary authority. On the risk relating to retail credit portfolios see Kaltofen et al. 2006).

At the same time, it is important to stress the difference between CRAs and Credit Rating Agencies like Standard \& Poor, Moody's, and Fitch. First of all, the latter provide different functions where they play a role in global market regulation and are authoritative gatekeepers for the issue and trading of debt securities (and no civil liberties or human rights are involved). Importantly, many States give official recognition to rating agencies that meet certain criteria. Moreover, according to scholars, the latter have acquired an "epistemic" authority which is less contestable than that of CRAs which, among other things, are the first ones to acknowledge the limits of their authority when claiming that they are simply information providers and bear no responsibility for decisions that are taken solely by lenders. See Olegario 2003, Schwarcz 2001, Jackson 2001
} 
On the practical side, admittedly, within the envisaged compromise solution, it could be the case that the substitution of CRA with cost-effective PCR would put the former out of business. It is hard to say whether this would be the necessary outcome or not. What can be noted is that CRA already engage in other activities that beyond data sharing and reporting. Examples are the various types of services that many CRA already provide to lenders, including credit scoring ${ }^{26}$ and data analysis for marketing or product development. They may make use of anonymised data or, as software or algorithm-providers, of personal data of each lender's own portfolio. These are only modest and incomplete examples. The suggestion, in the end, is that businesses, in order to survive new regulations or institutional reforms, would be required to innovate so as to adapt to the market which will develop from such changes, as happens with changes of whatever nature.

Almost certainly, the proposal put forward in this paper will raise further questions and controversy. At this stage, however, it is intended as an early policy consideration with the precise aim of being a starting point for stimulating further scholarly debate and research, particularly among lawyers, consumer organisations, regulators, and policy makers.

\section{References}

Agre, P. E. (1997). Introduction. In P. E. Agre \& M. Rotenberg (Eds.), Technology and privacy: The new landscape (pp. 1-28). Cambridge: MIT Press.

Bainbridge, D. (2005). Data protection law. $2^{\text {nd }}$ edn. St Albans: XPL Publishing.

Bainbridge, D., \& Pearce, G. (2000). Tilting at windmills - Has the new data protection law failed to make a significant contribution to rights of privacy? The Journal of Information, Law and Technology, 2000 (2).

Becker, L. (1977). Property Rights: Philosophical foundations. London: Routledge. Berger, A. N., \& Udell, G. F. (1995). Relationship lending and lines of credit in small firm finance. Journal of Business, 68, 351-381.

\footnotetext{
${ }^{26}$ Provided, of course, that the safeguards of Article 15 of the Directive are respected, i.e., that lenders even if they rely on the personal data of their own portfolio, respect the right of data subjects not to be subject solely to automated decisions, unless such decisions were taken at the data subject's request or unless there are arrangements in place allowing them to defend their point of view.
} 
Bertola, G., Disney, R., \& Grant, C. (2006). The economics of consumer credit demand and supply. In G. Bertola, R. Disney, \& C. Grant (Eds.), The economics of consumer credit (pp. 1-26). Cambridge: The MIT Press.

Bigus, J. P. (1996). Data mining with neural networks: Solving business problems from application development to decision support. New York: McGraw Hill.

Brealey, R. A., Clark, A., Goodhart, C., Healy, J., Hoggarth, G., LLewllyn, D. T. et al. (2001). Financial stability and central banks. London: Routledge.

Carey, P. (2004). Data protection - A practical guide to UK and EU law. $2^{\text {nd }} e d n$. Oxford: Oxford University Press.

Cartwright, P. (2004). Banks, consumers and regulation. Oxford: Hart Publishing 2004.

Deutsche Bundesbank. (2005). EU central banks open their registers for the crossborder exchange of information on loans to enterprises. Press Release. Frankfurt am Main: 7 June 2005. Available at http://www.bundesbank.de/download/presse/pressenotizen/2005/20050607bbk1 _en.pdf

Desai, V. S., Convay, D. G., Crook, J. N., \& Overstree, G. A. (1997). Credit scoring models in the credit union improvement using_neural networks and genetic algorithms. IMA Journal of Management Mathematics, 8(4), 323-346.

Diamond, D.W. (1991). Monitoring and reputation: The choice between bank loans and directly placed debt. Journal of Political Economy, 99, 689-721.

Diana, T. (2005). Credit risk analysis and credit scoring - Now and in the future. Business Credit, 2005(March) 1-3.

EGCH (Expert Group on Credit Histories). (2009). Report of the expert group on credit histories. May 2009. Available at:

http://ec.europa.eu/internal_market/consultations/docs/2009/credit_histories/egc h_report_en.pdf

European Commission. (2003a). Analysis and impact study on the implementation of Directive EC 95/46 in Member States. Brussels: 16 May 2003.

European Commission. (2003b). Report from the Commission-First report on the implementation of the Data Protection Directive (95/46/EC). COM (2003) 265 final.

European Commission. (2007a). A single market for $21^{\text {st }}$ century Europe. COM (2007) 724 final. 
European Commission. (2007b). Initiatives in the area of retail financial services. SEC (2007) 1520.

European Commission. (2008). Setting up an expert group on Credit Histories. C (2008) 2663 final.

European Commission. (2009a). Hearing on responsible lending and borrowing. MARKT/H3/SL D(2009).

European Commission. (2009b). Proposal for a regulation of the European Parliament and the Council on Community macro prudential oversight of the financial system and establishing a european systemic risk board of 23 September 2009. $\operatorname{COM}(2009) 499$ to 503 final.

Ferretti, F. (2007). The regulation of consumer credit information systems: Is the EU missing a chance? Legal Issues of Economic Integration, 34, 115-131.

Ferretti, F. (2008). The law and consumer credit information in the European Community. London: Routledge-Cavendish.

Ferretti, F. (2009). The credit scoring pandemic and the european vaccine: Making sense of the EU data protection legislation. Journal of Information, Law \& Technology, 2009(1), 1-24.

Fractal Analytics Ltd. (2003). Comparative analysis of classification techniques. A Fractal Whitepaper, September 2003.

Handzic, M., Tjandrawibawa, F., \& Jeo, J. (2003). How neural networks can help loan officers to make better informed application decisions. Informing Science,2003 (June), 97-109.

Heffernan, S. (2005). Modern banking. Chichester: John Wiley and Sons.

Howells, G. (1995). Data Protection, confidentiality, unfair contract terms, consumer protection and credit reference agencies. Journal of Business Law, 1995(4), 343-359.

Howells, G., \& Weatherill, S. (2005). Consumer protection law. Aldershot: Ashgate.

Jackson, H. E. (2001). The role of credit rating agencies in the establishment of capital standards for financial institutions in a global economy. In E. Ferran \& C. A. E. Goodhart (Eds.), Regulating financial services and markets in the twenty first century (pp. 311-322). Oxford: Hart Publishing.

Jappelli, T., \& Pagano, M. (2000). Information sharing in credit markets: The european experience. CSEF Working Paper No. 35, University of Salerno. 
Jappelli, T., \& Pagano, M. (2002). Information sharing, lending and defaults: Crosscountry evidence. Journal of Banking and Finance, 26, 2017-2045.

Jappelli, T., \& Pagano, M. (2003). Public credit information: A european perspective. In M. J. Miller (Ed.), Reporting systems and the international economy (pp. 81114). Cambridge: The MIT Press.

Jappelli, T., \& Pagano, M. (2006). Role and effects of credit information sharing. In: G. Bertola, R. Disney, \& C. Grant (Eds.), The economics of consumer credit (pp. 347-371). Cambridge: The MIT Press.

Jay, R., \& Hamilton, A. (2007). Data protection law and practice. $3^{\text {rd }}$ edn. London: Thomson Sweet and Maxwell.

Jensen, H. L. (1992). Using neural networks for credit scoring. Managerial Finance, $18,15-26$.

Jentzsch, N. (2005). Best world practices in credit reporting and data protection: Lessons from China. Paper prepared for the International Workshop on Household Credit, Peking University and University of Virginia.

Jentzsch, N. (2006). The economics and regulation of financial privacy. Heidelberg: Physica.

Kaltofen, D., Paul, S., \& Stein, S. (2006). Retail loans and Basel II: Using portfolio segmentation to reduce capital requirements. ECRI Research Report No. 8. Brussels: European Credit Research Institute.

Kuner, C. (2007). European Data Protection Law: Corporate compliance and regulation. Oxford: Oxford University Press.

Lastra, R. M. (1996). Central banking and banking regulation. London: Financial Markets Group LSE.

Lastra, R. M., \& Shams, H. (2001). Public accountability in the financial sector. In E. Ferran \& C. A. E. Goodhart (Eds.), Regulating financial services and markets in the twenty first century (pp. 165-188). Oxford: Hart Publishing.

Leader, S. (2006). Inflating consent, inflating function, and inserting human rights. In J. Dine \& A. Fagan (Eds.), Human rights and capitalism (pp. 28-47). Cheltenham: Edward Elgar.

Majinoni, G., Miller, M., Mylenko, N., \& Powell A. (2004). Improving credit information, bank regulation and supervision: On the role and design of public credit registries. Washington D.C.: World Bank Research Committee. 
Malloy, R. P. (2004). Law in a market context. Cambridge: Cambridge University Press.

Miller, M. J. (Ed.) (2003a). Reporting systems and the international economy. Cambridge: The MIT Press.

Miller, M. J. (2003b). Credit reporting systems around the globe: the state of the art in public credit registries and private credit reporting firms. In M. J. Miller (Ed.), Reporting systems and the international economy (pp. 25-80). Cambridge: The MIT Press.25-80.

Nieto, M. J., \& Penalosa, J. M. (2004). The european architecture of regulation, supervision and financial stability: A central bank perspective. Journal of International Banking Regulation, 5(3) pp. 228-242.

Olegario, R.(2003). Credit reporting agencies: A historical perspective. In M. J. Miller (Ed.), reporting systems and the international economy (pp. 115-159).

Cambridge: MIT Press.

Reifner, U. (2008). European Coalition for responsible credit principles of responsible credit. In C. Twigg-Flesner, D. Parry, G. Howells, \& A. Nordhausen (Eds.), The yearbook of consumer law (pp.419-427). Aldershot: Ashgate.

Rott, P. (2009). Consumer credit. In H. W. Micklitz, N. Reich, \& P. Rott P. Understanding EU consumer law (pp. 177-213). Antwerp: Intersentia.

San José Riestra, A. (2002). Credit bureaus in today's credit markets. ECRI Research Report No.4. Brussels: European Credit Research Institute.

Schwarcz, S. L. (2001). The role of rating agencies in global market regulation. In E. Ferran \& C. A. E. Goodhart (Eds.), Regulating financial services and markets in the twenty first century (pp. 297-310). Oxford: Hart Publishing.

Smith, A. (1776). An inquiry into the nature and causes of the wealth of nations. London: Methuen and Co.

Smith, A. (1790). The theory of moral sentiments. London: A. Millar.

Stiglitz, J. E., \& Weiss A. (1981). Credit rationing in markets with imperfect information. The American Economic Review, 71 (3), 393-410.

Stiglitz, J. E. (2006). Making globalisation work. London: Allen Lane.

World Bank. (1992). Governance and development. Washington, DC: World Bank.

Yobas, M., Crook, J. N., \& Ross, P. (2000). Credit scoring using neural and evolutionary techniques. IMA Journal of Management Mathematics, 11(2), $111-125$. 